\title{
A comparative study on the efficacy of drotaverine and valethamate on cervical dilatation during labour
}

\author{
Hema Sinhasane*, Nishty GM
}

Department of Obstetrics and Gynaecology, MR Medical College, Gulbarga, Karnataka, India

Received: 26 December 2016

Accepted: 31 December 2016

\section{*Correspondence:}

Dr. Hema Sinhasane,

E-mail: hemsan94@yahoo.com

Copyright: (C) the author(s), publisher and licensee Medip Academy. This is an open-access article distributed under the terms of the Creative Commons Attribution Non-Commercial License, which permits unrestricted non-commercial use, distribution, and reproduction in any medium, provided the original work is properly cited.

\section{ABSTRACT}

Background: The most common cause of prolonged first stage of labour is cervical spasm leading to cervical dystocia. Many times it is observed that inspite of good uterine contractions; cervix fails to dilate or dilates very slowly. This is functional cervical dystocia.

Methods: On admission detailed history was taken, complete general physical examination was made. Careful obstetric examination confirmed the lie, presentation, position of the foetus and FHP. Vaginal examination was made and the state of cervix (Dilatation, consistency and effacement) station of the vertex and type and adequacy of the pelvis was noted.

Results: A slight increase in the cervical tear is noted in the multrigravida in Group II. The incidence of PPH was double that of Group III. This was observed specifically when the drug was given after $5 \mathrm{cms}$ of dilatation of cervix. Conclusions: The maternal adverse effects were more with valethamate. Though there was transient fetal tachycardia with valethamate, the fetal outcome remained the same in all the groups.

Keywords: Cervical dystocia, Drotaverine, Valethamate

\section{INTRODUCTION}

Of all the journeys ever we make, the most dangerous is the very first one we make through the last $10 \mathrm{cms}$ of the birth canal. In the strategy of labour, the duration of the labour which has great influence on both maternal and perinatal morbidity. Years ago when watchful expectancy was the attitude of midwives, prolonged labour increased the risk of dehydration, ketoacidosis, infection traumatic deliver $y$ and fetal morbidity vix, hypoxia, infection. Modern times, "Active Management" trends towards curtailing the total duration of labour compatible with the safety of the mother and foetus. ${ }^{1}$

Drotaverine, an isoquinoline derivative, inhibits specifically phosphodiesterase IV (PDE IV) which in turn increases the intracellular concentration of cAMP and cGMP and causes smooth muscle relaxation. Inj.
Drotaverine Hydrochloride 40m is given intramuscularly. Valethamate is a mixture of diphenylpiperidino-propane ethylaisamide HCL. It has atropine like parasympatholytic action, Papaverine - like action on plain muscle and antihistaminic action. The drug reduces the hyperexcitability of parasympathetic system and lowers the spasm of smooth muscle system. Each ampoule of valethamate bromide F $08 \mathrm{mg}$ is given intravenously. ${ }^{2}$

Prolonged labour has been a dreaded problem for obstetricians. The most common cause of prolonged first stage of labour is cervical spasm leading to cervical dystocia. Many times it is observed that inspite of good uterine contractions; cervix fails to dilate or dilates very slowly. This is functional cervical dystocia. Methods that aim at minimizing the incidence of functional cervical dystocia and cutting short the first stage of labour are welcome by both obstetricians and women., ${ }^{3,4}$ Many 
spasmolytic drugs have been used and tried in the past, Drotaverine is a newer Spasmolytic drug acts by inhibiting phosphodiesterase enzyme IV, which is claimed to reduce the duration of labour by accelerating cervical dilatation without causing side effects.

Epidosin (valethamate bromide) is also an antispasmodic which helps in cervical dilatation due to its neurotropic or atropine like action and musculotropic or papaverine like action. Hence this study was carried out to compare the efficacy of Inj. Drotaverine with Inj Valethmate on duration of active phase of labour, the rate of cervical dilation and its effect on mother and foetus.

\section{METHODS}

This study was conducted at the department of Obstetrics and Gynecology. M R Medical College, Gulbarga Karnataka, India between September 2012 and June 2014. The planned sample number of patients was 200 in each group.

\section{Inclusion criteria}

- $\quad$ Primigravida multigravida up to $4^{\text {th }}$ gravida.

- Age 18-30 years

- $\quad$ Period of gestation 37-42 weeks

- Singleton pregnancy with cephalic presentation

- Uterine contractions of 2-3 in 10 min lasting for 30$40 \mathrm{sec}$

- Cervical dilatation around $3 \mathrm{cms}$ and $25-50 \%$ effaced

- Pelvis was adequate

On admission detailed history was taken, complete general physical examination was made. Careful obstetric examination confirmed the lie, presentation, position of the foetus and FHP. Vaginal examination was made and the state of cervix (Dilatation, consistency and effacement) station of the vertex and type and adequacy of the pelvis was noted. A cervicograph was maintained to note the cervical dilatation in all the three groups.

After inclusion patients assigned to Group I were given IM drotaverine $40 \mathrm{mg}$ at an interval of $2 \mathrm{hrs}$ up to a maximum of 3 injections. Group II patients received Inj. IV valethamate $8 \mathrm{mg}$ at an interval of $30-45 \mathrm{~min}$, up to a maximum of 5 injections. Group III patients did receive any spasmolytic i.e. control group.

Labour was accelerated by oxytocin infusion and amniotomy at around $5 \mathrm{cms}$ dilation. Strict monitoring of PR, RR, FHR, and BP was done before and after the injections. Uneasiness experienced by mothers such as dryness of mouth, vomiting, blurring of vision, palpitation etc. were noted. Internal assessment was done at 2 hourly interval for the rate of cervical dilatation, effacement, station of the vertex etc., and was noted on a partograph. Mode of delivery, duration of active phase of I-stage, II-stage and III-stage were noted. Cervical tears and PPH were noted. The number of injections given in each group was noted. APGAR for new born were recorded.

\section{RESULTS}

Out of 600 cases $41 \%$ (244) were primigravidas and $59 \%$ (356) were multi gravidas. The mean duration of $1^{\text {st }}$ stage in primigravida is $3 \mathrm{hrs} 50 \mathrm{~min}$ with drotaverine as compared to valethamate which is $4 \mathrm{hrs} 25 \mathrm{~min}$ and significantly shorter $(\mathrm{P}<0.05)$ than in the control group which is $6 \mathrm{hrs} 15 \mathrm{~min}$. Similarly in multigravidas it is 2 hrs $29 \mathrm{~min}$ as compared to Group II which is $3 \mathrm{hr} 21 \mathrm{~min}$ and shorter than Group III which is $5 \mathrm{hrs} 13 \mathrm{~min}(\mathrm{P}<0.05)$ (Table 1).

The rate of cervical dilatation in primigravidas in Group I $1.83 \mathrm{cms}$ as compared to Group II which is $1.58 \mathrm{cms}$ and is significantly $(\mathrm{P}<0.05)$ larger than Group III which is $1.12 \mathrm{cms}$ (Table 2).

Table 1: Duration of active phase of 1st stage of labour.

\begin{tabular}{|lllll|}
\hline & Primigravida & SD & Multigravida & SD \\
\hline Group I & $3 \mathrm{hr} 50 \mathrm{~min}$ & 159 & $2 \mathrm{hr} 29 \mathrm{~min}$ & 61.5 \\
\hline Group II & $4 \mathrm{hr} 25 \mathrm{~min}$ & 196.5 & $3 \mathrm{hr} 21 \mathrm{~min}$ & 111.5 \\
\hline Group III & $6 \mathrm{hr} 15 \mathrm{~min}$ & 194 & $5 \mathrm{hr} 13 \mathrm{~min}$ & 161 \\
\hline
\end{tabular}

Table 2: Mean rate of cervical dilatation.

\begin{tabular}{|lllll|}
\hline \multicolumn{1}{|c}{ Primigravida } & SD & Multigravida & SD \\
\hline Group I & $1.83 \mathrm{cms}$ & \pm 1.18 & $2.82 \mathrm{cms}$ & \pm 1.24 \\
\hline Group II & $1.58 \mathrm{cms}$ & \pm 1.05 & $2.08 \mathrm{cms}$ & \pm 1.26 \\
\hline Group III & $1.12 \mathrm{cms}$ & \pm 0.56 & $1.34 \mathrm{cms}$ & \pm 0.72 \\
\hline
\end{tabular}

Table 3: Mode of delivery.

\begin{tabular}{|llcc|}
\hline & LSCS & VAC/Forceps & NVD \\
\hline $\begin{array}{l}\text { Group } \\
\text { I }\end{array}$ & 21 & 14 & 165 \\
\hline $\begin{array}{l}\text { Group } \\
\text { II }\end{array}$ & 22 & 15 & 163 \\
\hline $\begin{array}{l}\text { Group } \\
\text { III }\end{array}$ & 24 & 15 & 161 \\
\hline
\end{tabular}

Similarly in multigravidas it is $2.82 \mathrm{cms}$ in Group I 2.08 $\mathrm{cms}$ in Group II and $1.34 \mathrm{cms}$ in Group III.

The incidence of LSCS in all the 3 groups was similar i.e., $12.7 \%$ in Group I $13.5 \%$ in Group II and 14.9 in Group III, which is statistically insignificant (Table 3).

A slight increase in the cervical tear is noted in the multrigravida in Group II. The incidence of PPH was double that of Group III. This was observed specifically when the drug was given after $5 \mathrm{cms}$ of dilatation of cervix (Table 4). 
Table 4: Incidence of cervical tear and PPH.

\begin{tabular}{|lllll|}
\hline & Primigravida & Multigravida & Primigravida & Multigravida \\
\hline Group I & 0 & 2 & 3 & 5 \\
\hline Group II & 1 & 1 & 2 & 1 \\
\hline Group III & 0 & 4 & 2 & 2 \\
\hline
\end{tabular}

Table 5: Average number of injections.

\begin{tabular}{|lllll|}
\hline & No. of cases & No. of Inj. & No. of cases & No. of inj \\
\hline Group I & 87 & 1.94 & 113 & 1.08 \\
\hline Group II & 81 & 3.64 & 119 & 2.42 \\
\hline
\end{tabular}

Table 6: Side effects.

\begin{tabular}{|llll|}
\hline $\begin{array}{l}\text { Dryness of } \\
\text { mouth }\end{array}$ & 5 & 27 & 6 \\
\hline Vomiting & 3 & 4 & 2 \\
\hline Palpitation & 1 & 21 & 6 \\
\hline $\begin{array}{l}\text { Transient foetal } \\
\text { tachycardia }\end{array}$ & 3 & 118 & 4 \\
\hline
\end{tabular}

The average number of injections required as shown in (Table 5) are 1-2 in case of drotaverine with a maximum of 3 injections 3-4 in case of valethamate with a maximum of 5 injections. The number of injections of valethamate required is more than double the injections of drotaverine.

Table 7: Neonatal outcome.

\begin{tabular}{|llll|}
\hline APGAR & Group I & Group II & Group III \\
\hline $8 / 10$ & $96 \%$ & $97.5 \%$ & $98.5 \%$ \\
\hline
\end{tabular}

The adverse effects like palpitation (10.5\%), vomiting (2\%), Dryness of mouth $(13.5 \%)$ and transient fetal Tachycardia (59\%) were noted in Group II (Table 6). The APGAR was better with Group III where no drug was used but with no statistical difference with other groups.

\section{DISCUSSION}

A study was conducted to compare the efficacy of drotaverine and epidosin in shortening the duration of first stage of labour. Three hundred demographically similar women with full term pregnancy in active labour were included in the study and divided in two groups viz. drotaverine group $(\mathrm{N}=250)$ given drotaverine intramuscularly at $3-4 \mathrm{~cm}$ dilatation two hourly and epidosin group $(\mathrm{N}=50)$ were given epidosin intramuscularly at $3-4 \mathrm{~cm}$ dilatation one hourly. Comparative analysis was carried out as regards duration of various stages of labour, rate of cervical dilatation, side effects and fetomaternal outcome. ${ }^{5}$
Duration of active phase of first stage was $116.34 \pm 59.44$ and $158.78 \pm 58.98$ minutes in group I and II respectively. Rate of cervical dilatation was $3.99 \pm 2.21$ and $2.74 \pm 1.72 \mathrm{~cm} /$ hour in group I and II respectively. They observed drotaverine to be a better drug for cervical dilatation than epidosin. ${ }^{6}$

In another study, it was conducted to know the effect of drotaverine and valethamate bromide on the duration of labour. A randomized prospective study was carried out on 300 women in normal labour. The results were the mean duration of first stage of labour was $132.67 \pm 60.24$ minutes in the epidosin group, $175.92 \pm 90.56$ minutes in the drotaverine group and $287.68 \pm 104.1$ minutes in the control group. They concluded that both epidosin and drotaverine were highly effective; epidosin was better in multipara in shortening the duration of labour. ${ }^{7}$

A study was designed to evaluate the effect of drotavaerine on cervical dilatation, and compare its efficacy with epidosin. The study was carried out on 150 patients which included both primigravidae and multigravidae who were at term in the early active phase of labour. The average rate of cervical dilatation in primigravidae with inj. drotin, an isoquinoline derivative was $2.05 \mathrm{~cm} /$ hour and with inj. epidosin $1.53 \mathrm{~cm} /$ hour. In multigravidae it was $3.68 \mathrm{~cm} /$ hour and $2.00 \mathrm{~cm} /$ hour respectively. The average time taken from $3 \mathrm{~cm}$ to full dilatation of cervix was 3 hours 25 minutes with drotaverine and 4 hours 35 minutes with epidosin in primis and 1 hour 45 minutes and 3 hours 30 minutes in multis. ${ }^{8}$ Our results were consistent with Demeter J. ${ }^{9}$

\section{CONCLUSION}

Drotaverine is a potent and safe cervical dialator. The rate of cervical dilatation with drotaverine is significantly more than valethamate.

Funding: No funding sources

Conflict of interest: None declared

Ethical approval: The study was approved by the Institutional Ethics Committee 


\section{REFERENCES}

1. Rohwor AC, Khondowe O, Young $\mathrm{T}$. Antispasmodics for labour. Cochrane Database Syst Rev. 2013 Jun 5;(6):CD009243.

2. Madhu C, Mahavarkar S Bhave S. A randomised controlled study comparing Drotaverine hydrochloride and Valethamate bromide in the augmentation of labour. Arch Gynecol Obstet. 2010;282(1):11-5.

3. Gupta B, Nellore V, Mittal S. Drotaverine hydrochloride versus hyoscine-N-butylbromide in augmentation of labor. Int $\mathrm{J}$ Gynaecol Obstet. 2008;100(3):244-7.

4. Ibrahim MI, Alzeeniny HA, Ellaithy MI, Salama AH, Abdellatif MA. Int J Gynaecol Obstet. 2014;124(2):112-7.

5. Singh KC, Jain P, Goel N, Saxena A. Drotaverine hydrochloride for augmentation of labor. Int $\mathrm{J}$ Gynecol Obstet. 2004;84(1):17-22.
6. Devinder K, Ravinder K. Comparison of drotaverine and epidosin in first stage of labor. J Obstet Gynecol India. 2003;53(5):449-52.

7. Khosla AH, Bala I, Dahiya K, Sangwan K. A comparative study of the efficacy of valethamate bromide with drotaverine in normal labor. J Obstet Gynecol India. 2003;53(6):568-70.

8. Mishra SL, Toshniwal A. Effect of drotaverine on cervical dilatation: A comparative study with epidosin (valethamate bromide). J Obstet Gynecol India. 2002;52(3):76-9.

9. Demeter J, Blasko S. The effect of intramuscularly administered drotaverine on the dilatation stage of uncomplicated deliveries. Obstet Gynecol. 1998;3:723-37.

Cite this article as: Sinhasane H, Nishty GM. A comparative study on the efficacy of drotaverine and valethamate on cervical dilatation during labour. Int $\mathrm{J}$ Reprod Contracept Obstet Gynecol 2017;6:423-6. 